\title{
Governmentality and the Power of Transnational Women's Movements
}

\author{
CAROL HARRINGTON
}

Victoria University of Wellington, New Zealand

\begin{abstract}
Feminists have celebrated success in gendering security discourse and practice since the end of the Cold War. Scholars have adapted theories of contentious politics to analyze how transnational feminist networks achieved this. I argue that such theories would be enhanced by richer conceptualizations of how transnational feminist networks produce and disseminate new forms of global governmental knowledge and expertise. This article engages social movement theory with theories of global governmentality. Governmentality analysis typically focuses upon governmental power rather than political contention or the collective agency of political outsiders. However, I argue that governmentality analysis contributes to an account of feminist influence on the fields of development and security within global politics. The governmentality lens views politics as a struggle over truth and expertise. Since experts have authority to speak the truth on a given issue, governmentality analysis seeks to uncover the social basis of expertise. Such analysis of expertise can illuminate important aspects of the power of movements. The power of transnational women's movements lies in production and dissemination of knowledge about women within global knowledge networks.
\end{abstract}

\section{Introduction}

Social movement accounts of women's movements' impact conceptualize movement power as compelling masculine elites to act against their own preferences through mechanisms of leverage and framing. From this perspective, elites compromise in the face of persuasive rhetoric and lobbying. Social movement theory posits a clear divide between elites and nonelites, situating social movements as acting for the excluded. Nevertheless, movement theorists acknowledge the significance of networks between social movement organizations and elites to their success. After reviewing social 
movement perspectives, this article argues that governmentality theory offers a fuller account of the power of women's organizations. Governmentality theory focuses upon the social effects of knowledge and posits a less dichotomized understanding of power than social movement theory. I show how international women's movement organizations originating in Europe and the US during the nineteenth century established themselves as experts on women, as a global category suffering inequality. Women's organizations set up sections around the globe, collecting narratives of women's oppression and data on women. They supported global institutions dedicated to defending global categories of people oppressed by states or by statelessness. This article considers the contribution of women's organizations to knowledge of women as a population category within development and, more recently, security. The global power of women's movements lays in how such movements constructed women as a category for concern nested within discourse and knowledge of civilizational hierarchies that delineate particular populations and territories as objects for international governmental intervention.

\section{Social Movement Theories of the Power of Movements}

Social movement studies addresses problems of power, political exclusion and collective resistance to oppression, thus providing a useful framework for analyzing feminism. Leading social movement theorists, Charles Tilly and Sidney Tarrow, distinguish between political elites who have routine access to public decision makers and the majority of people who have limited means to influence government (Buechler, 2011, pp. 125-140; Tilly, 1985). Tilly provided a detailed historical analysis of "contentious performances" such as strikes, street theatre, petitions and demonstrations in Great Britain from 1758-1834, a period when distinctive new forms of collective action emerged among European non-elites. When contentious political actors develop sustained social networks and self-organization then, Tarrow argues, we can speak of a "social movement" (Tarrow, 2011, p. 16). Thus, the concept "social movement" captures a distinctive combination of political campaign, repertoire of contention and public display that emerged in Europe and North America from about the mid-eighteenth century and included women's movements.

Women's movement organizations emerged in Europe and the US when faster international transport, printing technologies and the spread of literacy created possibilities for new kinds of collective action and imaginings of political community. While new notions of national sovereignty threatened old empires by fuelling national movements new ideals of individual rights created grounds for movements based in transnational identifications which sought influence on distant governments and social practices. Douglas Stange recounts how in the mid-nineteenth century Unitarian abolitionists in the United Kingdom felt justified in chastising US Unitarians about the evils of slavery because "America was no longer a distant land it was only 
two weeks away" (Stange, 1984, p. 96). People and ideas travelled rapidly while increasing literacy among politically excluded workers, women and slaves provided them with, in the words of fugitive slave Frederick Douglass, "tongue to interesting thoughts of my own soul which had frequently flashed through my mind and died away for want of utterance" (Douglass 1845, 39). Narratives of oppression and treatises on social reform circulated around the globe among abolitionists, pacifists, socialists, and workers, women's and black associations, among others.

International associations of all kinds proliferated throughout the long nineteenth-century. New associations formed out of political debates within established groups. For example, by excluding women the 1840 World Anti-slavery Congress in London laid the ground for an 1888 International Congress of Women in Washington DC which founded the International Council of Women (ICW) headquartered in Zurich (Whittick, 1980, p. 22). Still active today, the ICW set out to build national sections around the world which would provide women a voice within their states and allow for sharing information internationally. The International Women's Suffrage Alliance formed in 1904 out of dissatisfaction with the ICW's refusal to campaign for the vote (Whittick, 1980, p. 22). The first international women's association also had roots in abolitionism, Josephine Butler's International Federation for the Abolition of the State Regulation of Vice, founded in 1875 (Berkovitch, 1999 , p. 160). This association formed in opposition to a call from an 1873 International Medical Congress for international co-ordination on state regulation of prostitution so as to prevent disease travelling across borders (Berkovitch, 1999, p. 35). According to Berkovitch, between 1875 and 1914 twenty two international women's organizations formed alongside numerous other international organizations seeking social reform (Berkovitch, 1999, p. 160).

Social movement theorists analyze movement power as a form of compulsion, where political outsiders find a way to exercise leverage over elites. Tilly's emphasis on social movements' public displays of "worthiness, unity, numbers and commitment" emphasizes movement influence as residing in their capacity to compel political change against elite preferences (Tilly \& Wood, 2009, pp. 4-5). Confronted with repeated public displays of mass commitment to change, elites sometimes feel compelled to surrender or compromise on social movement demands to ensure the stability of the broader political order. Social movements may also exercise leverage through recruiting elite actors to their cause. While elites have routine access to public decision making they may have political cause to align themselves with social movements. Thus, while women's movements emerged through political exclusion they have thrived on alliances with political insiders and according to Keck and Sikkink (1998) successfully employed leverage politics.

Keck and Sikkink (1998) combine social network analysis and social movement theory in their analysis of "transnational advocacy networks" which they define as "those relevant actors working internationally on an issue, who are bound together by shared values, a common discourse and 
dense exchanges of information and services" (p. 2). Such networks include actors from social movements, NGOs, media, academia, foundations, regional and international intergovernmental organizations and the state. Their work calls attention of the connectedness of women's movement networks and broader governmental processes involving media, state, academic and intergovernmental bodies. In their case study of the international campaign on violence against women Keck and Sikkink (1998) argue that activists succeeded by coordinating transnational networks to campaign for states and intergovernmental organizations to support particular internal reforms, such as changing police practices, and to use their influence on other states and organizations in favour of the reform.

As well as power through leverage politics, social movement theorists use the concept of "framing" to analyze how movements exercise persuasive power by consciously framing their grievances in politically compelling ways. For example, Keck and Sikkink's discussion of international feminist advocacy on violence against women relates how in the early 1990s feminist activists began to promote the slogan "women's rights are human rights" and to frame violence against women as a human rights violation. This framing situated the problem "within larger 'master frames' or 'metanarratives' of violence and rights" (Keck \& Sikkink, 1998, p. 196). Keck and Sikkink (1998) analyze the success of this campaign in terms of the "adjacency principle" whereby movements that manage to line up their claim in terms of already accepted instances of political injustice and violations of rights have greater impact (p. 196). In their account:

The women's rights campaign is a story of self-conscious activists who are simultaneously principled and strategic. They are principled in their motivation for action: international feminist activists believed deeply in equality and rights for women everywhere. But they chose their organizing foci and campaign tactics strategically. They hoped to build alliances with women worldwide, knowing it would be difficult. (p. 196)

According to this analysis: "it was the activists themselves who created the category [of violence against women], and who, through their organizing, placed it on the international agenda" (Keck \& Sikkink, 1998, p. 196). This version of framing theory attributes the construction of new political categories to clever actors' manipulation of meaning and reflexive understanding of existing political frames.

From this point of view, feminist political leadership located in US-based UN women's networks constructed a new social category: violence against women. Keck and Sikkink (1998) argue that "when wife battering or rape in the United States, female genital mutilation in Africa, and dowry death in India were all classified as forms of violence against women, women could interpret these as common situations and seek similar root causes" (p. 197). This new categorization linked disparate female experiences around the globe as similarly violent and pointed to male dominance as the cause. Furthermore, feminist leaders successfully persuaded legal elites that "violence against 
women" should be counted as a human rights violation, and in particular circumstances as genocidal violence, a crime against humanity and a war crime. Feminist leaders, or "issue entrepreneurs" as Keck and Sikkink call them, consciously deployed this framing for the political end of uniting women across borders in opposition to male dominance.

Like much social movement theory, Keck and Sikkink's adoption of framing theory over-emphasizes purposeful political leadership in the construction of social categories and issues. Thus, while they discuss how activists re-framed various gendered acts as violence against women and a human rights violation they take for granted that human rights provided a compelling frame for interpreting such acts. Additionally, they suggest that bodily integrity violations provide an intrinsically compelling issue (Keck \& Sikkink, 1998, p. 195). Their analysis treats bodily integrity and human rights as self-evident categories available for feminist deployment. Yet genealogical analysis of the governmental categories "human rights", "bodily integrity" and "women" reveals that they have undergone rapid political transformation in mutual interaction during the late twentieth and early twenty first century (Harrington, 2010). These shifts in meaning shaped feminist campaigns' claims to expertise and ability to enter into discourse on global security.

The value of social movement theory lies in its focus upon delineating movements as vehicles for collective agency of people who do not have access to elite decision making. However, social movement theory treats political struggle as concerned with leverage, compulsion, and conscious persuasion. Below, I argue that women's movements do not simply compel elites to make concessions and cleverly manipulate words and images, women's movements produce governmental knowledge and truth about populations subject to government. By looking at women's movements through the governmentality lens, my analysis highlights how they participated in the construction of rationalities and techniques for governing women's inequality and unfreedom. The power of women's movements lies in their construction of knowledge about women as a transnational category of persons.

\section{Global Governmentality and Women's Movements}

Governmentality offers a richer framework for understanding the power of movements than concepts of framing and leverage. Michel Foucault (1990) famously connected power to resistance in his introduction to The History of Sexuality V1, with his oft-quoted claim that power and resistance always occur together and resistance should not be viewed as exterior to power (p. 95). Governmentality theory continues Foucault's conceptualization of power as productive of resistant subjects rather than as oppressing pre-given subjects. Yet, with some exceptions, a gap in governmentality theory concerns the resistance of those governed (Zanotti, 2011, p. 31). In a review article Merlingen (2006) notes that most governmentality literature investigates how governmental techniques work to produce particular forms of conduct rather 
than how government produces resistant subjects (p. 190).

Foucault's concept of power avoids static oppressor/oppressed dichotomies and allows analysis of how resistant subjects may themselves claim governmental authority and produce resistant knowledge. Women's movements emerged in resistance to masculine power and claimed power through knowledge. Resistance to the masculine liberal governmental gender order manifested as women's movements in Europe and the US. These movements problematized female unfreedom and crafted their own authority to govern women as a transnational category of persons. European and US women's movement organizations acted as an engine for the construction of new liberal governmental problems and knowledge clustered around questions of gender inequality.

Foucault (1991) gave the term governmentality two related meanings: mentalities of government and government of mentalities. In the former sense of the term, governmentality refers to mentalities, or knowledge, of appropriate government, encompassing answers to questions who or what should be governed by whom, how they should govern, and why government is necessary in specific contexts (Rose, O'Malley, \& Valverde, 2009, p. 3). Governmentalities treat government as thoughtful human activity, both science and art. They delineate domains of governmental knowledge and practice such as the economy, society and the state. Governmentalities delineate populations, peoples and places and specify techniques for intervening in them. International women's movements that participate in the UN system established themselves as experts on women as a global category of people and asserted that women knew best how to govern other women (Berkovitch, 1999; Harrington, 2010; Rupp, 1997).

Equally importantly, the term also refers to "government of mentalities" signalling how concerns with shaping subjectivities and producing appropriate forms of personhood permeate governmental practices. Thus, Nikolas Rose (1996) suggests that governmentality analysis requires a genealogy of personhood that attends to: problematizations of types, personhood, or conduct, the authoritative knowledge that produces problematizations, the technologies used to change problematized persons or conduct, and how problematizations and technologies fulfil broader objectives concerning proper government (pp. 131-134). Much work on governmentality focuses upon the mutual construction of welfare states and free but responsible forms of personhood (Barry, Osborne, \& Rose, 1996; Cruikshank, 1999; Dean \& Hindes, 1998; Rose, 1999).

Womenhood became a global category within global governmental processes. Larner and Walters (2004) call for genealogical analysis of "global governmentality" which would investigate fields of expertise and knowledge such as "development," "modernization," "global economy" and "global security." Global governmentalities produce non-state spaces of government, such as "the developing world," or the global south or east. Global governmentalities also delineate populations such as women as requiring government outside of state frameworks and sometimes as needing 
defence against the states in which they reside. Some scholars use the term "developmentality" to analyze governing mechanisms that shape distant populations to conform to the development agendas of wealthy and powerful actors (Deb, 2009; Fendler, 2001; Ilcan \& Phillips, 2010).

The women's movements originating in Europe and the US during the nineteenth century shaped twentieth century global governmentalities through their production and dissemination of knowledge more than in bending political elites to the will of the masses. Their power lay in embedding feminist knowledge within governmental institutions and practices. They constructed alternative problems for government, such as "gender inequality," or "violence against women". They contributed to $20^{\text {th }}$ century global governmentalities by constructing women as a transnational category with shared problems in need of international resolution.

Nineteenth-century European and US women's organizations claimed to represent women across the globe and set up sections in colonized countries. In their formal politics international women's organizations aspired to a vision of women as sharing common political problems while respecting differences. Rupp's research on early twentieth century women's organizations shows the tension involved in this stance because US groups had much more funding than others and both European and US women's organizations sought to mentor women in other countries. Black women formed separate organizations because of racism in the International Women's Suffrage Alliance (Rupp, 1997, p. 75). During the inter-war and post war period, European and US led international women's organizations emphasized national differences as well as shared experience. They often supported national independence movements and sought to encourage the emergence of national women's leadership and organizations (Rupp, 1997).

Women's organization networks and knowledge made their support politically valuable to European and American elite efforts at constructing post-colonial forms of global government as old empires gave way to pressure from nationalist movements. As internationalists, women's organizations agreed on the need for inter-governmental congresses and treaties to address social issues and called for an inter-governmental organization which could regulate international space and mediate international conflict. Women's movement organizations provided an important constituency supporting the League of Nations and the International Labour Organization following World War I and the United Nations following World War II (Miller, 1994; Rupp, 1997; Seary, 1996, p.20).

Several women's organizations established at the turn of the century gained governmental status and expertise within international governmental organizations, among them the ICW and some of its offshoots. The International Labour Organization, League of Nations and UN all consulted women's organizations on matters such as female employment and trafficking in women (Berkovitch, 1999; Leppänen, 2009; Reanda, 1999; Willetts, 1996). Women's organizations also monitored the activities of these international bodies (Miller, 1994). Their relentless advocacy led the League of Nations 
to establish a Committee of Experts on women that formed the basis for the United Nation's Committee on the Status of Women. Thus, the establishment of the United Nations ushered in a period in which women had become a problematized category of people requiring international government based upon particular forms of knowledge and expertise.

As women's movement organizations contributed to the construction of international intergovernmental institutions and processes these institutions shaped women's movement organizations around the globe. The UN constructed its accountability and responsibility in relation to transnational citizens' associations rather than simply to state members: The UN could address and govern transnational collectives of individuals such as "workers," "women" or "displaced people" and even defend these people against states. The United Nations coined the term "non-governmental organization" (NGO) and carefully regulated which organizations counted as "international" and their eligibility for consultative status with its Economic and Social Council (ECOSOC) (Willetts, 1996, p. 40). UN definitions of NGOs eligible for ECOSOC consultative status emphasize that they should have independence from national governments and accountability to an international membership (Willetts, 1997, p.42). Usually, the UN stipulates that consultative NGOs should represent transnational entities, such as "workers," "women," professional associations such as teachers or doctors, and international associations devoted to cross border questions, such as the environment, disease control, trafficking in people and goods, displaced peoples and so forth (ECOSOC, 1996, p. 31).

\section{Women's Organizations and Developmentality}

Women's international organizations have recognized authority only to speak on topics that international governmental elites consider "women's issues" which became a subcategory of other governmental problems. Governmental knowledge forms within broader institutional discourses which categorize problems for government in terms of "economy," "development," "culture," "human rights," "security" and so forth. These categories shape discursive possibilities in the formation of social knowledge. For much of the twentieth century international policy on women as women took place in the UN development bureaucracy. International women's NGOs advocated for women within a governmentality that rationalized governmental interventions in distant economies and populations because it would help them develop toward the model of wealthy countries.

The earliest US and European international women's organizations, which later participated in UN politics, articulated grievances based in their comparative knowledge of women's experiences of poverty, illiteracy and health problems. By the late nineteenth century states increasingly collected population statistics and social science information about populations (Cole, 2000). In this context, women's movement organizations established 
themselves as knowledgeable about the government of women and keepers of statistics on women. Indeed, European and US women's movements pioneered the sorts of calculative governmental practices that governmentality theory has highlighted. Governmentality analysts emphasize the significance of calculative practices to government of populations at a distance. International governmental organizations collect population statistics, comparing and ranking populations against each other and with quantifiable governmental goals and standards. Suzan Ilcan and Lynne Phillips note that the UN's calculative practices have been crucial to global governmentalities that attempt to standardize the conduct of populations in terms of fields such as education, consumption and trade (Ilcan \& Phillips, 2010, p. 850). Likewise, Michael Merlingen analyzed the OSCE's practice of ranking and grading east European countries according to their treatment of ethnic minorities as involving surveillance, examination and normalizing judgement that allows the European Union to discipline populations to its east (Merlingen, 2003).

Measurement and reporting on democratization, human rights and women's status attempts to render these social issues as amenable to technocratic management by global authorities. The International Council of Women produced knowledge that constructed gender inequality as a measurable social problem amenable change through social policy. Their Bureau of Information kept country statistics on women's employment, education and activities. In 1909 they asked national councils to report on legal inequalities in their respective countries and in 1912 published a report documenting gender inequality in seventeen countries (Berkovitch, 1999, p. 3; International Council of Women., 1912). As Berkovitch observes, "using standardized measures, the status of women is compared to that of men, and the gap that is found (and it always is) is defined as discrimination considered to be a social problem and treated as an injustice to be rectified and corrected through state action and state policy" (Berkovitch, 1999, p.3).

Thus, European and US women's organizations struggled for inclusion in global government by producing data and ranking countries in terms of women's freedom. They promoted international standards on women's status. Within development discourse feminist scholars emphasized how improving women's educational, health and economic status would have positive outcomes for both child well-being and economic growth, thus instrumentalizing women's well-being as contributing to elite governmental goals (Boserup, 1970). Women's advocates within the UN system won resources for the field of "women and development" which constructed women as mothers and marginalized workers and made "third world women" a particular object of concern (Kabeer, 1994; Mohanty, 1991).

International women's organizations advocated for women within a developmentality that rationalized international bodies' governmental interventions in distant economies and populations because it would help them develop toward the model of wealthy countries. Gendered knowledge of populations contributed to a global governmentality which divided the globe according to "advanced" civilizations where women enjoyed 
political equality and nurtured small healthy families and "under-developed" civilizations where women had more children than they could adequately nurture and suffered because of such cultural norms as arranged marriage and polygamy.

Throughout the twentieth century, British and North American feminist arguments for women's rights depended upon liberal civilizational discourse, contrasting the patriarchal cultures of the East with the relative gender egalitarianism of the West and equating gender equality with modernization and progress. For example, an influential book in defining British and US images of women in the colonies, Katherine Mayo's Mother India (1927), made child marriage in India a political issue in Britain and led to the Child Marriage Restraint Act, 1929 (Liddle \& Rai, 1998, p. 503). As Liddle and Rai point out, while focusing on the abuse of women and girls Mayo's argument locates the causes of this abuse in the backward culture typical of colonised people, drawing parallels between Indians and Filipinos in their cultural brutality and need for government by a superior civilization (Mayo was also author of Isles of Fear: the truth about the Phillippines, published in 1925). Mayo presents the solution to Indian women's oppression in continued British rule, while ignoring indigenous women's liberation campaigns against such abuse and the abuse of Indian women by British men. Mayo's work influenced the Anglo-American stereotype of the abused eastern, or third world woman in need of rescue, which has continued to shape British and American feminist discourse. For example, Liddle and Rai point out that such a classic feminist text as Mary Daly's Gyn/Ecology: the metaethics of radical feminism (Daly, 1978) actually uses Mayo as a source about gender customs in India (Liddle \& Rai, 1998, pp. 495-520). Along similar lines, Jo Doezema analysed discourses produced by the Coalition against Trafficking of Women showing that position of "third world woman" in such discourse is innocent victim of brutal patriarchal cultures (Doezema, 2001, pp. 16-38).

Empowerment discourse provided an important point of intersection between women's movement organizations and distant donors and governmental actors. Barbara Cruickshank (1999) wrote about welfare state social policy that aimed to empower women victims of male violence imagined as helpless and in need of state intervention in their day to day lives. She argued that liberal governmentality produced empowerment as a rationale for governing free individuals by constructing particular kinds of people, such as female victims, as unfree. Critical work on empowerment has highlighted how it allows distant authorities to micro-manage the lives and political struggles of individuals in target populations. Empowerment individualizes political problems such as poor health or exposure to violence and disease (Finn \& Sarangi, 2008).

Gender empowerment discourse also reinscribes global civilizational hierarchy. Ilcan and Phillips (2010) critiqued the millennium development goals for reformulating and standardizing political priorities, including how to measure "gender empowerment." The "gender empowerment index" (GEM) purports to measure women's influence in economic and political 
life and produces country rankings, concerning itself with "agency" rather than "well-being" (Klasen, 2006, p. 257). The value given to income in construction of the GEM makes wealthy countries likely to score high and poor countries likely to score low (Klasen, 2006, p. 258). Thus, the index provides quantitative confirmation of a civilizational hierarchy whereby men from wealthy countries treat "their" women better and thus prove their superiority.

\section{Women's Organizations, Advanced Liberal Governmentality and Global Knowledge Networks}

The language of empowerment frequently characterizes programs based in "advanced governmentality". Technologies of agency and responsibilization provide important themes of advanced liberal governmentality. Scholars developed theories of advanced liberalism in analysis of late twentieth century transformations in welfare state policies which sought to "responsibilize" and "empower" people to take care of their own health, education and well-being. According to Dean (2009), "technologies of agency" engage the governed in monitoring and correcting their own conduct, treating them as responsible agents capable of meeting governmental norms and targets once provided with appropriate information and training.

Advanced liberal global governmentalities seek to responsibilize and empower developing countries to find solutions to their own economic problems. Donor states and organizations recast their relationship with aid recipients as "partnerships" whereby aid projects and priorities would be decided upon by the communities they sought to assist (Abrahamsen, 2004). Donors also sought to work with NGOs "on the ground" rather than through state agencies (Musto, 2008, pp. 9-10). Private actors, businesses and NGOs, rather than states, became cast as the drivers of development (Fowler, 2000 , p. 2). Following the end of the Cold War changes in the regulation of international markets created an environment more favourable for NGOs to receive funding from distant donors (Pinter 2001, p. 198).

Advanced liberal governmentality favours networks and short term contracts as the best formations for governmental interventions at a distance. Government increasingly takes place through networks of state, international governmental organizations (IGOs, for example the World Bank, IMF, United Nations) and NGOs, the latter including NGOs with social movement links. Networks often exist as a series of contracted partnerships between donors, transnational NGOs and community based NGOs. Such networks produce and circulate information, theories and techniques of government. A governmental program, such as a rape crisis centre, at any given location may depend on the activity of both local and transnational feminist groups, human rights and humanitarian NGOs, local government, state institutions, philanthropic foundations, corporate donors and international organizations. Such networks furnish global governmental actors with data on women and techniques for "empowering women" at various locations. 
New practices of contracting women's NGOs to deliver services and provide gender policy advice fuelled a late twentieth century "NGO boom" among women's organizations (Alvarez, 2009, p. 175). Sonia Alvarez (2009) argues that the resources for research and communications provided by international donors had allowed feminism to develop from a movement on the streets to an authoritative governmental discourse because NGOs could afford to conduct and disseminate research on women's social conditions.

As the vast constellation of knowledge products generated by NGOs wind their way through feminisms' multi-layered political-communicative webs, they also often cross over into other (overlapping) networks of social movements, civil society organizations, and social and political institutions. Feminisms' discursive "baggage" thus sometimes travels "unaccompanied," so to speak. (Alvarez, 2009, p. 178)

Scholars of human rights NGOs have noted that transnational movements' influence occurs through a politics of information fuelled by professional NGO research (Ron, Ramos, \& Rodgers, 2005). This politics of information involves not simply collecting and disseminating data and narratives but also theories and analysis. Furthermore, NGOs frequently produce and disseminate techniques of government in the form of training materials and models of service provision.

From a governmentality perspective, women's organizations participate in a global knowledge network made up of a "fluid configuration[s] of organizations, institutions, groups and people" concerned with gendered human conduct (Ilcan \& Phillips 2008, pp. 713-714). Women's movement based NGOs provide significant nodal points in this network because of their capacity to produce and disseminate knowledge of women and theories of gender (Alvarez, 2009, p. 177). Global knowledge network theory develops governmentality theory to emphasize how mobile knowledge, expertise and governmental techniques construct forms of personhood that facilitate the government of distant populations. Visions of appropriate forms of personhood provide points of intersection between contentious actors at a given location and distant authorities seeking to influence that location. Thus, global knowledge networks emerge within broader governmental configurations around shared teleologies, values, and practices concerning appropriate forms of personhood. These networks facilitate movement of knowledge, expertise, and governmental techniques around the globe in efforts to foster particular habits, conduct, and self-understandings.

\section{Global Security and Female Empowerment}

Feminist discourse and knowledge travels alongside the most coercive manifestations of global governmentality. As Dean observed, although liberal governmentality developed as a critique of authoritarian government it does not exclude coercive governmental techniques; liberal security practices often 
have a simultaneous coercive and capacitating dimension (Dean, 2002, p. 42). Post Cold War UN peacekeeping practices exemplify this dimension of advanced liberal global governmentality. The UN has become more hands-on in monitoring and co-ordinating negotiated peace settlements, supervision of post-conflict administrative structures, constitutional, judicial and electoral reforms, elections, economic reconstruction, humanitarian assistance, monitoring of human rights and implementation of refugee return programs. Thus, questions formerly categorized as to do with development have become security issues and underdevelopment conceptualized as a security risk. These advanced liberal security practices construct security as dependent upon liberal markets and constitutional models (Duffield, 2001; Gaer, 2003; Jaeger, 2010; Richmond, 2003). Within liberal security rationality the deployment of armed force anywhere on the globe can be justified by the need to secure human rights and humanitarian goals, including the bureaucracies and NGO networks required to monitor such goals. The UN sanctions armed forces in the form of military personnel, police and private security contractors. Such operations routinely seek links with local women's organizations and include an institutional nod to gender expertise in the form of under resourced gender officers or focal points (Harris \& Goldsmith, 2010; Olsson, 2001; Ospina, 2006; Puechguirbal, 2003).

Violence against women forms a significant theme in post-Cold War peacekeeping and democracy-building discourse. Narratives of violence against women and other atrocities justify military interventions to protect women from violent men who adhere to backward patriarchal cultures and routinely violate human rights (Hunt, 2006; Sagan, 2010). Peacekeeper training materials represent women in post conflict zones as likely traumatized by sexual violence (DPKO, 2002; Harrington, 2006). The most significant efforts to document violence against women globally developed alongside new forms of peacekeeping and international justice (Buss, 2007; Harrington, 2010a, pp. 124-127). In December 1992, the Security Council declared itself "appalled by reports of the massive, organized and systematic detention and rape of women, in particular Muslim women, in Bosnia and Herzegovina" and these reports formed part of the case for intervention (Resolution 798). In 1994 the UN General Assembly appointed a special rapporteur on gender based violence began producing information on violence against women around the globe (Pietilä and Vickers, 1996, pp.142-145; United Nations 1993, 1994, 1996a; 1996b, 1996c, UNHCR 1993). Regional powers now monitor violence against women in their sphere of influence, for example Australian and New Zealand police run domestic violence programs for police from Tonga, Samoa, the Cook Islands and Kiribati (PPDVP 2010; AFP 2010).

Authoritative knowledge of violence against women remains the province of feminist discourse and women's organizations. The earliest women's movements in Europe and the US produced narratives of marital violence and other violations of female bodily integrity (Trumble, 2004). Feminists argued that women had a special interest in peace because of wartime sexual 
violence (Ogden \& Sargant, 1915). Quantification of violence against women developed in the 1970s and 1980s as part of resurgent feminist activism on the issue (Gavey, 2005). Feminist efforts at quantifying violence against women linked with human rights efforts at documenting torture and analysis of bodily violation as psychological trauma (Harrington, 2010b, pp. 98-117). Feminist knowledge provided numbers and narratives that made sense of military intervention and increased international policing.

The UN adopted the slogan the power to empower which casts female peacekeeping security personal, including soldiers and police, as agents of empowerment of women in countries subjected to international military intervention in the name of liberal peace and democracy. UN publicity materials cast female peacekeepers as role models for women in postconflict situations (e.g. United Nations 2010, 2009). The slogan power to empower has even been worked into a song for UN peacekeepers, employing social movement practices of building unity through song (United Nations Police Division Female Global Effort, 2011). The UN seeks to connect peacekeeping to feminism through representing peacekeeping policewomen as a manifestation of "female global effort." Publicity materials emphasize UN policing as empowering to women in countries where the UN deploys armed force. Oddly, the UN facebook page publicity about activities of female police represent their performance of mundane disciplinary activities such as arresting female drunk drivers, while a BBC documentary following female peacekeepers in Sierra Leone showed them harassing marijuana smoking homeless teenagers (BBC, 2007; United Nations Police Division Female Global Effort, 2011).

\section{Conclusion}

While the social movement lens has focused more upon resistant political processes than governmentality research, global knowledge network theory provides a fuller account of transnational feminist networks' impact on global politics. The power of international women's organizations lies in production and dissemination of knowledge and techniques for the government of women as a cross border population category. Development and global security, as major post-colonial fields of knowledge and power, have engaged with knowledge of female poverty and insecurity produced by internationally networked women's organizations. Women's movements originating in Europe and North America during the nineteenth century engaged in calculative practices from their foundations. However, measures of gender empowerment and other liberal calculative practices that rank or score states according to gender equality typically conform to global hierarchies that rank Europe and North America as models for the rest of the world to emulate. 


\section{References}

Abrahamsen, R. (2004). The power of partnerships in global governance. Third World Quarterly, 25(8), 1453-1467.

Alvarez, S. E. (2009). Beyond NGO-ization?: Reflections from Latin America. Development, $52(2), 175-184$.

Barry, A., Osborne, T., \& Rose, N. (1996). Foucault and political reason: Liberalism, neoliberalism, and rationalities of government (1st ed.). University Of Chicago Press.

Basu, A. (2000). Globalization of the local/localization of the global mapping transnational Women's Movements. Meridians, 1(1), 68-84.

BBC. (2007). All Girl Squad. Retrieved from http://news.bbc.co.uk/2/hi/programmes/this world/6221094.stm

Berkovitch, N. (1999). From motherhood to citizenship: Women's rights and international organizations. Baltimore: John Hopkins University Press.

Boserup, E. (1970). Woman's role in economic development. London: Allen \& Unwin.

Buechler, S. M. (2011). Understanding social movements: Theories from the classical era to the present. London: Paradigm Publishers.

Buss, D. (2007). The curious visibility of wartime rape: Gender and ethnicity in international criminal law. Windsor Yearbook of Access to Justice, 25(1). Retrieved from http://papers.ssrn. com.helicon.vuw.ac.nz/sol3/papers.cfm?abstract_id=1816438

Cole, J. (2000). The power of large numbers: population, politics, and gender in nineteenthcentury France. Ithaca and London: Cornell University Press.

Cruikshank, B. (1999). The will to empower: democratic citizens and other subjects. Ithaca and London: Cornell University Press.

Daly, M. (1978). Gyn/ecology, the metaethics of radical feminism. Boston: Beacon Press.

Dean, M. (2009). Governmentality: Power and rule in modern society. Sage Publications Ltd.

Dean, M., \& Hindes, B. (1998). Governing Australia: Studies in contemporary rationalities of government. Cambridge: Cambridge University Press.

Deb, D. (2009). Beyond developmentality: Constructing inclusive freedom and sustainability. London: Earthscan.

Doezema, J. (2001). Ouch!: Western feminists" "wounded attachment" to the "Third World prostitute." Feminist Review, 67 (Spring), 16-38.

DPKO. (2002). Gender and peacekeeping operations: generic training. Department of Peacekeeping Operations. New York: United Nations

Duffield, M. (2001). Global governance and the new wars: The merging of development and Security. London: Zed Books.

ECOSOC. (1996). Resolution 1996/31 Consultative relationship between the United Nations and non-governmental organizations. Retrieved from http://www.un.org/documents/ecosoc/ res/1996/eres1996-31.htm

Fendler, L. (2001). Educating flexible souls: The construction of subjectivity through developmentality and interaction. In K. Hultqvist \& G. Dahlberg (Eds.), Governing the child in the new Millennium. London: RoutledgeFalmer.

Finn, M., \& Sarangi, S. (2008). Quality of life as a mode of governance: NGO talk of HIV "positive" health in India. Social Science \& Medicine, 66(7), 1568-1578.

Foucault, M. (1990). The History of Sexuality, Vol. 1: An Introduction. (R. Hurley, Tran.). New York: Vintage.

Foucault, M. (1991). Governmentality. In G. Burchell, C. Gordon, \& P. Miller (Eds.), The Foucault effect: Studies in governmentality (pp. 87-104). Hemel Hempstead: Harvester Wheatsheaf.

Fowler, A. (2000). Introduction beyond partnership: Getting real about NGO relationships in the aid system. IDS Bulletin, 31(3), 1-13.

Gaer, F. D. (2003). Human Rights NGOs in UN Peace Operations. International Peacekeeping, $10(1), 73-89$.

Gavey, N. (2005). Just sex?: The cultural scaffolding of rape. London: Routledge.

Harrington, C. (2010). Politicization of sexual violence: From abolitionism to peacekeeping. London: Ashgate Pub. Company.

Harrington, C. (2006). Governing peacekeeping: the role of authority and expertise in the case of sexual violence and trauma. Economy and Society, 35(3), 346-380. 
doi: $10.1080 / 03085140600844910$

Harris, V., \& Goldsmith, A. (2010). Gendering transnational policing: Experiences of Australian women in international policing operations. International Peacekeeping, 17(2), 292.

Hunt, K. (2006). Embedded feminism and the war on terror. In Engendering the war on terror: War stories and camouflaged politics (pp. 51-72). London: Ashgate.

Ilcan, S., \& Phillips, L. (2008). Governing through global networks. Current Sociology, 56(5), $711-734$.

Ilcan, S., \& Phillips, L. (2010). Developmentalities and calculative practices: The millennium development goals. Antipode, 42(4), 844-874.

International Council of Women. (1912). Women's position in the laws of the nations: A compilation of the laws of different countries, prepared by the I. C. W. Standing Committee on laws concerning the legal position of women with an introduction by Mme: d'Abbadie d'Arrast : Publ. by authority of the International Council of Women. Karlsruhe: G. Braunsche Hofbuchdruckerei und Verlag.

Jaeger, H.-M. (2010). UN Reform, biopolitics, and global governmentality. International Theory, 2(1), 50-86.

Kabeer, Naila. 1994 Reversed realities: Gender hierarchies in development thought London: Verso.

Keck, M. E., \& Sikkink, K. (1998). Activists beyond borders: Advocacy networks in international politics. Ithaca: Cornell University Press.

Klasen, S. (2006). UNDP's Gender related measures: Some conceptual problems and possible solutions. Journal of Human Development, 7(2), 243-274.

Larner, W., \& Walters, W. (2004). "Globalization as Governmentality.” Alternatives: Global, Local, Political, 29(5), 495-514.

Leppänen, K. (2009). The conflicting interests of women's organizations and the League of Nations on the question of married women's nationality in the 1930s. NORA-Nordic Journal of Feminist and Gender Research, 17(4), 240.

Liddle, J., \& Rai, S. (1998). Feminism, imperialism and orientalism: the challenge of the Indian woman. Women's History Review, 7(4), 495-520.

Merlingen, M. (2003). Governmentality. Cooperation and conflict, 38(4), 361 -384.

Merlingen, M. (2006). Foucault and world politics: Promises and challenges of extending governmentality theory to the European and beyond. Millennium - Journal of International Studies, 35(1), $181-196$.

Miller, C. (1994). "Geneva - the key to equality": inter-war feminists and the league of nations. Women's History Review, 3(2), 219.

Mohanty, C. T. (1991) "Cartographies of struggle: Third world women and the politics of feminism," and "Under western eyes: Feminist scholarship and colonial discourses" in C. Talpade Mohanty, A. Russo, \& L. Torres (Eds), Third World Women and the Politics of Feminism (pp.51-80). Bloomington: Indiana University Press.

Musto, J. (2008). The ngo-ification of the anti-trafficking movement in the United States: a case study of the coalition to abolish slavery and trafficking. Wagadu, 5. Retrieved from http:// appweb.cortland.edu/ojs/index.php/Wagadu/article/viewArticle/288

Ogden, C. K., \& Sargant, F. M. (1915). Militarism vs. feminism. London: Allen and Unwin. Retrieved from http://digital.library.upenn.edu/women/florence/feminism/feminism.html

Olsson, L. (2001). Gender mainstreaming in practice: The United Nations transitional assistance group in Namibia. International Peacekeeping, 8(2), 97.

Ospina, S. (2006). A review and evaluation of gender-related activities of UN peacekeeping operations and their impact on gender relations in Timor Leste. New York: Department of Peacekeeping Operations. Retrieved from http://www.peacewomen.org/assets/file/ Resources/UN/dpko_timorlesteevaluation_2006.pdf

Pietilä, H., \& Vickers, J. (1996). Making women matter: The role of the United Nations. $3^{\text {rd }}$ edition. London: Zed Books.

Pinter, F. (2001) "Funding global civil society organisations" in H. Anheier, M. Glasius, \& M. Kaldor (Eds), Global civil society. Oxford: Oxford University Press

Puechguirbal, N. (2003). Gender training for peacekeepers: Lessons from the DRC - PB Routledge. International Peacekeeping, 10(4), 113.

Reanda, L. (1999). Engendering the United Nations. European Journal of Women's Studies, $6(1), 49-68$. 
Richmond, O. P. (2003). Introduction: NGOs, peace and human security. International Peacekeeping, 10(1), 1.

Ron, J., Ramos, H., \& Rodgers, K. (2005). Transnational information politics: NGO human rights reporting, 1986-2000. International Studies Quarterly, 49(3), 557-588.

Rose, N. (1999). Powers of freedom: Reframing political thought. Cambridge: Cambridge University Press.

Rose, N. (1996). Identity, genealogy, history. In S. Hall \& P. Du Gay (Eds.), Questions of cultural identity (pp. 128-150). London: Sage.

Rose, N., O’Malley, P., \& Valverde, M. (2009). Governmentality. University of Sydney, Sydney Law School, Legal Studies Research Paper No 09/94. Retrieved from http://papers.ssrn.com/ sol3/papers.cfm?abstract_id $=1474131$

Rupp, L. J. (1997). Worlds of women: the making of an international women's movement. New Jersey: Princeton University Press.

Sagan, A. (2010). African criminals/African victims: The institutionalised production of cultural narratives in international criminal law. Millennium - Journal of International Studies, 39(1), 3-21.

Seary, B. (1996). "The early history: From the Congress of Vienna to the San Francisco Conference" in P. Willets (Ed.), The conscience of the world": The influence of nongovernmental organisations in the UN system (pp.15-30). London: Hurst and Company.

Stange, D. C. (1984). British Unitarians against American slavery, 1833-65. London: Associated University Presses.

Tarrow, S. (2011). Power in movement: Social movements and contentious politics. New York: Cambridge University Press.

Tilly, C. (1985). War making and state making as organized crime. In P. Evans, D. Rueschemayer, \& T. Skocpol (Eds.), Bringing the state back in. Cambridge: Cambridge University Press.

Tilly, C., \& Wood, L. J. (2009). Social movements, 1768-2008. London: Paradigm Publishers.

United Nations. (2009). Women in peacekeeping: The power to empower. Retrieved from http:// www.youtube.com/watch? $=$ =vAuFQj9xBYc\&feature $=$ relmfu

United Nations. (2010). Female police peacekeepers: In their own voices. Retrieved from http:// www.youtube.com/watch? $=$ =b_NuG0tj3BA\&feature=relmfu

United Nations. (1996). Economic and social council. Commission on human rights. Report of the Special Rapporteur on Violence Against Women, its Causes and Consequences, Ms. Radhika Coomaraswamy, Submitted in Accordance with Commission on Human Rights Resolution 1995/85, E/CN.4/1996/53.

United Nations. (1994). Economic and social council. Commission on human rights. Preliminary Report Submitted by the Special Rapporteur on Violence against Women, its Causes and Consequences, Ms. Radhika Coomaraswamy, in Accordance to Commission on Human Rights Resolution 1994/45, E/CN.4/1995/42.

United Nations. (1993). Economic and social council. Commission on human rights. Rape and Abuse of Women in the Territory of the Former Yugoslavia. Report of the Secretary General. E./CN.4/1994/5.

United Nations General Assembly Resolution. (1993). Declaration on the elimination of violence against women. A/Res/48/104. $85^{\text {th }}$ plenary meeting, 20 December. Retrieved from http:// www.un.org/documents/ga/res/48/a48r104.htm

United Nations Security Council. Resolution 798. 1992. Adopted by the Security Council at its $3150^{\text {th }}$ meeting on 18 December 1992. S/Res/798 Retrieved from http://daccess-dds-ny. un.org/doc/UNDOC/GEN/N92/828/82/IMG/N9282882.pdf?OpenElement

Zanotti, L. (2011). Governing disorder: UN peace operations, international security, and democratization in the post-cold war era. University Park, PA: Pennsylvania State University Press. 